\title{
Assessment of Natural Uranium in the Ground Water around Jaduguda Uranium Mining Complex, India
}

\author{
N. K. Sethy ${ }^{1 *}$, R. M. Tripathi ${ }^{2}$, V. N. Jha ${ }^{1}$, S. K. Sahoo ${ }^{2}$, A. K. Shukla ${ }^{2}$, V. D. Puranik ${ }^{2}$ \\ ${ }^{1}$ Environmental Assessment Division, Bhabha Atomic Research Centre, Health Physics Unit, Jaduguda Mines, Jharkhand, India; \\ ${ }^{2}$ Bhabha Atomic Research Centre, Mumbai, India. \\ Email: ${ }^{*}$ sethybarc@rediffmail.com
}

Received May $16^{\text {th }}, 2011$; revised July $15^{\text {th }}, 2011$; accepted August $27^{\text {th }}, 2011$.

\begin{abstract}
Ground water ecosystem surrounding the uranium processing facility at Jaduguda, India has been studied for natural uranium distribution. Annual intake of uranium through drinking water for members of public residing around the uranium complex is found to be in the range of $41.8 \mathrm{~Bq} \cdot \mathrm{y}^{-1}-44.4 \mathrm{~Bq} \cdot \mathrm{y}^{-1}$. The intake and ingestion dose is appreciably low $\left(<2 \mu \mathrm{Sv} \cdot \mathrm{y}^{-1}\right)$ which is far below the WHO recommended level of $100 \mu \mathrm{Sv} \cdot \mathrm{y}^{-1}$. The excess life time radiological risk due to uranium natural in drinking water is insignificant and found to be of the order of $10^{-6}$. Even the highest concentration of uranium was found to be $28 \mu \mathrm{g} \cdot \mathrm{l}^{-1}$ is away (at 1.5 to $5 \mathrm{~km}$ distance) from mining industry and well below the acceptable limit. The ground water in the area around the uranium facility is not affected by the mining activity. The ground water in three zones is safe and reflects the natural distribution of uranium.
\end{abstract}

Keywords: Natural Uranium, Ingestion Dose, Radiological Risk

\section{Introduction}

\subsection{General Description}

Rapid industrialization and subsequent waste disposal has been a concern for ground water contamination. Ground water is the major source of drinking water in many parts India. Industrial activities, metal mining and waste depositary may contribute to the nearby ground water sources by radionuclide migration. Mining and processing of uranium in the east-Singbhum region of Jharkhand has been started in early sixties. Uranium ore is mined from a cluster of mines (Jaduguda, Bhatin and Narwapahar, Turamundih, Bagjata, Mauldih) spreading in the region and processed at centralized ore-processing plant at Jaduguda using hydrometallurgy technique. As the ore is of very low grade $\left(<0.05 \% \mathrm{U}_{3} \mathrm{O}_{8}\right)$, a huge quantity of process waste (tailings) is generated and disposed safely in tailings ponds. Tailings pond is an engineered having valley with natural hills on three sides and earthen bund forming the fourth side. Engineering features of the earthen bund ensures the decantation of dissolved radionuclides, which are treated further for removal of the toxins $\left(\mathrm{U},{ }^{226} \mathrm{Ra}\right.$ and heavy metals) prior to their discharge into the aquatic ecosystem. The change in physicochemical characteristics of tailings over the period may take place leading to dissolution of some of the contaminants. The migration of these contaminants into the adjoining ground water sources can be anticipated. Evaluation of ingestion dose and subsequent risk due to intake of water to population residing around the tailings pond is the subject matter of this study. The mining complex comprises of uranium mines, ore processing plant and tailings ponds. The study area is situated at Jaduguda $\left(22^{\circ} 30^{\prime} \mathrm{N}\right.$ and long. $\left.85^{\circ} 40^{\prime} \mathrm{E}\right)$ in the East Singbhum district of Jharkhand, India. The area is well known for its wide mineral deposits and receives $>1000$ $\mathrm{mm}$ of rain fall annually. The maximum temperature in summer is $>45^{\circ} \mathrm{C}$ and minimum is $<7^{\circ} \mathrm{C}$ during winter.

\subsection{Health Hazard of Uranium}

Toxicity of uranium has been established by animal studies and human data from uranium miners and workers with accidental exposures indicate that uranium affects the proximal tubules of the kidney; at very high acute doses, tubular degeneration and necrosis (that is, death of tissue) may occur a few days after the intake of 
uranium [1]. Kidney is generally considered to be the critical organ for uranium through water or food. The uranyl ion forms bicarbonate, citrate and $\mathrm{UO}_{3}\left(\mathrm{CO}_{2}\right)_{3}$ complexes in blood plasma [2]. The $\mathrm{UO}_{2}^{++}$ion binds with the red blood cells. During the purification of blood in kidney, it is filtered from the blood and then recombines with the cell surface ligands. Studies on uranium toxicity studies in human have been described elsewhere $[3,4]$. Though, intake of uranium by members of the public can occur through various routes. However the principal route of ingestion of uranium is through drinking water [5] and to a lesser extent through the foodstuff. Intake of uranium through drinking water by population residing around the uranium mining area has been considered in the present study. United States Environmental Protection Agency (EPA) has classified uranium as a group- A human carcinogen. It has prescribed maximum contaminant level goal (MCLG) for uranium as 0 (zero) in 1991(zero tolerance). In drinking water, EPA suggests maximum contaminant level as (MCL) of $30 \mu \mathrm{g} \cdot 1^{-1}$ [6]. In Canada, the proposed interim maximum acceptable level is (IMAC) of $20 \mu \mathrm{g} \cdot \mathrm{l}^{-1}$, whereas World Health Organization (WHO) strictly recommended a reference level as $2 \mu \mathrm{g} \cdot 1^{-1}[7]$.

\section{Materials and Methods}

\subsection{Sampling and Analysis}

Grab samples (5 lit) were collected from open wells and tube wells situated at various distances in the public domain. The area around the uranium mining Industry is divided into three zones i.e. $<1.5 \mathrm{~km}, 1.5$ to $5 \mathrm{~km}$ and $>5$ $\mathrm{km}$. Ground water samples were collected from these three zones. Sample locations were selected covering three measure season of the area (October to March, April to June and August to September) on the basis of public utility and down stream direction from uranium industry. More number of samples was collected from downstream side of the Uranium Industry. Samples were brought to the laboratory filtered and preserved in acidic medium. About $100 \mathrm{ml}$ of water sample is evaporated to dryness and $20 \mathrm{ml}$ of $0.25 \mathrm{~N}$ electronic grade pure $\mathrm{H}_{2} \mathrm{SO}_{4}$ is added and reflux for 30 minutes in a hot plate. It is then cooled and transferred to a separating funnel/tube. Then $20 \mathrm{ml}$ of alamine-benzene ( $2 \%$ alamine in $98 \%$ benzene) solution is added and the mixture is shaken for few minutes with occasionally opening the mouth of the separating tube to vent off the gases formed inside. The aqueous phase is drained out and $0.1 \mathrm{ml}$ from organic phase is taken for planchatting in a platinum disc. The basic principle of estimation of natural uranium in environmental sample is to quantitatively transfer the trace amount of uranium present in the sample aliquot to a small platinum disc and measure the intensity of florescence of uranium compound. A small volume $(0.1 \mathrm{ml})$ of organic media containing the uranium is transferred to platinum disc, fused with $250 \mathrm{mg}$ of $\mathrm{NaF}-\mathrm{Na}_{2} \mathrm{CO}_{3}(15: 85)$ fusion mixture at $800^{\circ} \mathrm{C}$ for 3 minutes. Cooled and fluorescence intensity was measured in ECIL, make Fluorimeter (Model No: FL6224A) [8].

UV radiation of excitation wavelength $3650 \AA$ is irradiated on the platinum disc containing fused sample and emitted florescence of $5546 \AA$ wavelength is unique to uranium [9]. Intensity of fluorescence is proportional to the amount of uranium present in the sample. Standard (1 $\mathrm{ug} / \mathrm{ml}$ ) and blank were processed simultaneously and uranium was estimated by using the formula

$$
\mathrm{U}(\mu \mathrm{g})=\frac{\text { Sample reading }- \text { Blank reading }}{\text { Standardreading }- \text { Blank reading }}
$$

The uranium content of the original sample was obtained from the above equation by further applying the sampling parameters. The advantage of this method is aqueous to organic ratio is not critical and may be varied over a wide range. There is no need of any salting out reagent and organic phase can directly planchatted. The disadvantage of this method is that the fusion mixture is hygroscopic and measurement of fluorescence intensity should be measured without giving much delay. The detection limit of this method is $0.1 \mu \mathrm{g}$.

\subsection{Quality Control}

Quality assurance of the analytical procedure followed was determined by using certified reference materials (SRMs) produced by Canada Center for Mineral and Energy Technology (CANMET) and supplied by Bureau of analysed samples Ltd., UK. Environmental reference sample such as lake sediments (LKSD-1\&3), stream sediment (STSD-1) and geochemical soil (TILL-1\&2) were analysed for natural uranium. The result of the analysis is presented in Table 3.

\section{Result and Discussions}

\subsection{Distribution of Uranium in water and Intake}

The histogram of uranium concentration in ground water around the uranium mining industry over the study period is presented in Figure 1. A year wise geometric mean concentration of uranium in the ground water sources in different distance zones is presented in Table 1. However, the maximum concentration of $U(n a t)$ within $1.6 \mathrm{~km}$ distance was observed at $11 \mu \mathrm{g} \cdot \mathrm{l}^{-1}$ with GM of $1.13 \mu \mathrm{g} \cdot \mathrm{l}^{-1}$ and GSD of 2.64 during the entire study period. The large variation in the uranium concentration is due to uneven distribution of uranium in the lithosphere. Further, the histogram plot (Figure 2) of the data set reveals that in majority of ground water sources 


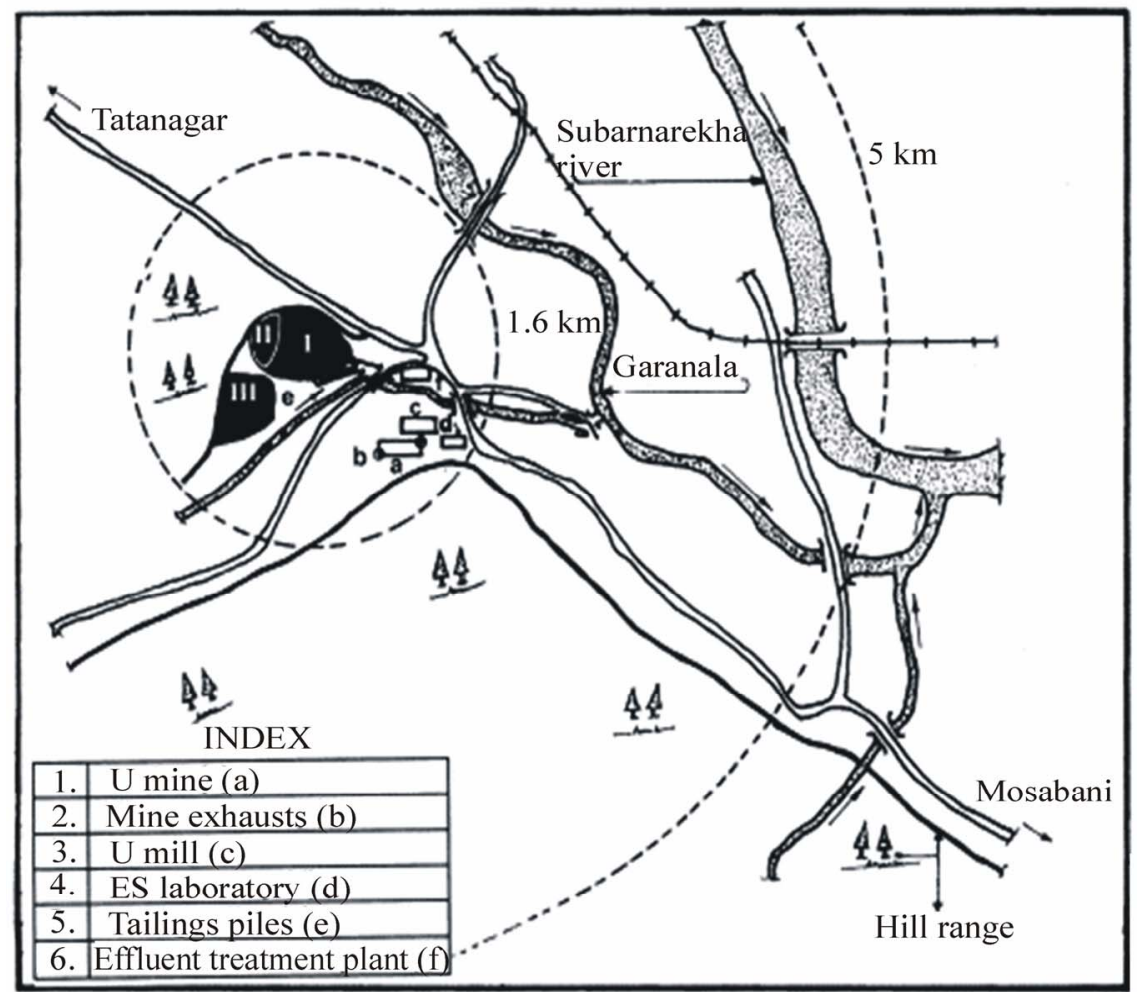

Figure 1. The Environmental map of Uranium Mining Complex, Jadugoda, India.

Table 1. Concentration of U(nat) in ground water samples in various distance zones.

\begin{tabular}{|c|c|c|c|c|}
\hline Distances from T.P (km) & No of samples (N) & Year & $\mathrm{U}($ nat $)\left(\mu \mathrm{g} \cdot \mathrm{l}^{-\mathbf{1}}\right)$ & Geo Mean (GSD) \\
\hline & & 2003 & Range & \\
\hline$<1.6$ & 8 & & $0.5-11$ & $1.62(3.1)$ \\
\hline $1.6-5.0$ & 17 & & $0.5-20$ & $1.21(3.2)$ \\
\hline \multirow[t]{2}{*}{$>5.0$} & 20 & & $0.5-4.7$ & $1.0(2.5)$ \\
\hline & & 2004 & & \\
\hline$<1.6$ & 15 & & $0.5-7.6$ & $1.39(3.0)$ \\
\hline $1.6-5.0$ & 15 & & $0.5-28$ & $2.8(3.7)$ \\
\hline \multirow[t]{2}{*}{$>5.0$} & 10 & & $0.5-4.3$ & $2.79(3.5)$ \\
\hline & & 2005 & & \\
\hline$<1.6$ & 16 & & $0.5-7.6$ & $1.31(2.9)$ \\
\hline $1.6-5.0$ & 16 & & $0.5-19$ & $2.39(3.2)$ \\
\hline \multirow[t]{2}{*}{$>5.0$} & 11 & & $0.5-4.3$ & $1.49(2.2)$ \\
\hline & & 2006 & & \\
\hline$<1.6$ & 5 & & $0.5-2.3$ & $0.86(2.1)$ \\
\hline $1.6-5.0$ & 4 & & $0.5-1.2$ & $0.76(1.45)$ \\
\hline \multirow[t]{2}{*}{$>5.0$} & 17 & & $0.5-4.7$ & $1.37(3.9)$ \\
\hline & & 2007 & & \\
\hline$<1.6$ & 15 & & $0.5-1.5$ & $0.71(1.5)$ \\
\hline $1.6-5.0$ & 9 & & $0.5-3.1$ & $1.0(1.9)$ \\
\hline$>5.0$ & 10 & & $0.5-3.5$ & $0.78(1.9)$ \\
\hline
\end{tabular}




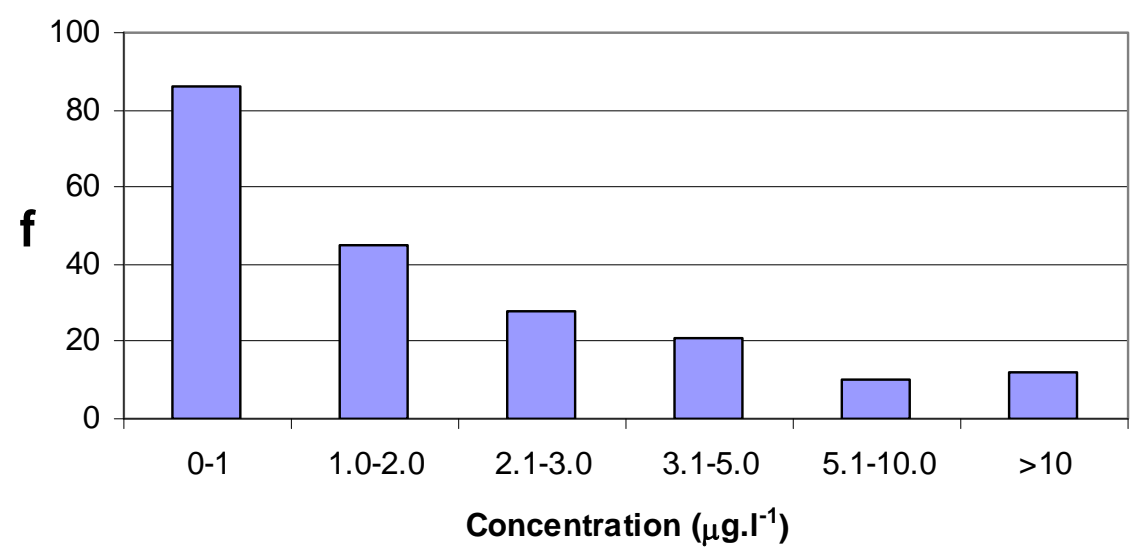

Figure 2. Histogram of $U$ in Ground water.

the concentration was less than $0.5 \mu \mathrm{g} \cdot \mathrm{l}^{-1}$. The distribution of $\mathrm{U}$ (nat) during the study period in the distance zone $1.6 \mathrm{~km}-5 \mathrm{~km}$ was varied with GM concentration of $1.2 \mathrm{mg} \cdot \mathrm{m}^{-3}$ and GSD of 3.4. The maximum concentration in this zone was $28 \mu \mathrm{g} \cdot \mathrm{l}^{-1}$. In the case of natural unmined ore deposits uranium can enter the ground water by way of leaching of uranium bearing rock strata by the ground water aquifers. The physicochemical environment around the source has great influence on distribution of uranium natural in ground water. In this context solubility of uranium in the medium is probably playing a vital role. Only the hexavalent uranium compounds are soluble which is favored by aerobic condition of the environment. The less soluble tetravalent fraction can get dissolved and variation in the levels can be expected even within the same geological formations. Apart from this $\mathrm{pH}$, competing ions, complex formation with uranyl ions, seasonal variations are also leading to variable distribution of uranium in the ground water. During the study period, in the distance zone of $>5 \mathrm{~km}$, distribution of U(nat) was varied with GM of $1.13 \mu \mathrm{g} \cdot \mathrm{l}^{-1}$ and GSD of 2.28. One way ANOVA (Table 2) reveals that there is insignificant variation in uranium natural concentration at different distances from the tailings pond with Chi-square $>p$ 0.052 . The maximum concentration within a distance of $1.6 \mathrm{~km}$ was appreciably low as compared to the recommended national regulatory standard of $60 \mu \mathrm{g} \cdot \mathrm{l}^{-1}$ based on the $\mathrm{F}$ class radiological consideration. Since uranium appearing in drinking water is soluble uranium the most restrictive radiological class has been considered for recommending the limits. In other zone also the recommended limit of $60 \mu \mathrm{g} \cdot \mathrm{l}^{-1}$ has not been exceeded so far. The significantly lower concentration within a distance of $1.6 \mathrm{~km}$ from uranium industry is attributed to the local geological features of the area. This also confirms that so far there has been insignificant migration of $\mathrm{U}$ (nat) from the operation of uranium industry to the adjoining ground water sources. The present study is compared with similar studies carried out in other countries (Table 5) as well as in India. The concentration range in ground water in the present study, as evident in Table $\mathbf{5}$ is comparable to study carried out in Turkey [10] but lower than similar studies in USA [11,12].

\subsection{Radiation Dose and Risk}

A five year study of ground water as discussed earlier showed natural uranium was in low concentration range. Though mass concentration of natural uranium was measured in ground water samples it can be expressed in activity concentration using conversion factor of 25 $\mathrm{mBq} \cdot \mu \mathrm{g}^{-1}$. Uranium level $\left(\mathrm{Bq} \cdot \mathrm{m}^{-3}\right.$ or $\left.\mu \mathrm{g} \cdot \mathrm{l}^{-1}\right)=$ Measured mass concentration $\left(\mu \mathrm{g} \cdot \mathrm{l}^{-1}\right) \times$ Conversion factor $(25$ $\mathrm{mBq} \cdot \mathrm{gg}^{-1}$ ) Considering the daily intake of water for Indian reference man $4.051 \cdot \mathrm{d}^{-1}[13,14]$, dose conversion factor of $0.045 \mu \mathrm{Sv} \cdot \mathrm{Bq}^{-1}[15]$ the annual ingestion dose to the adult individual residing around the tailings pond due to natural uranium was estimated. Since the data distribution in the three zones can be approximated by log normal the intake and ingestion dose should be based on geometric mean. Accordingly the annual intake from drinking water in the three zones discussed can be estimated to be $41.8,44.4$ and $41.8 \mathrm{~Bq} \cdot \mathrm{Y}^{-1}$ with an ingestion dose of 1.88, 2.0 and $1.88 \mu \mathrm{Sv} \cdot \mathrm{Y}^{-1}$ respectively. This is far lower than the [16] recommended guideline of 100 $\mu \mathrm{Sv} \cdot \mathrm{Y}^{-1}$ for ingestion from the intake of a single radionuclide. Health effects due to exposure of uranium can be classified as radiological risk as radioactive element and chemical risk as a heavy metal. Radiological risk was evaluated using the risk coefficient $4.40 \times$ $10^{-11}$ per pCi as per the US EPA [17] standard method. The radiological risk was converted to excess lifetime risk by multiplying with activity concentration of uranium level in ground water. While estimating the risk average body weight $(52 \mathrm{~kg})$ and water intake by Indian 
Table 2. Kruskal-Wallis One-Way ANOVA for U(nat) variation around tailings pond.

\begin{tabular}{|c|c|c|c|c|c|}
\hline Source & SS & df & MS & Chi Square & Prob $>$ Chi-Square \\
\hline Distance & 10898.2 & 2 & 54449.1 & 5.89 & 0.052 \\
\hline Error & 270313.3 & 150 & 1802.09 & & \\
\hline Total & 281211.5 & 152 & & & \\
\hline
\end{tabular}

Table 3. Concentration of Uranium in certified reference materials.

\begin{tabular}{cccc}
\hline Reference Material & Unit & Certified Concentration & Observed Concentration \\
\hline LKSD 1 & $\mu \mathrm{g} \cdot \mathrm{g}^{-1}$ & 9.7 & $8.8 \pm 0.4$ \\
LKSD 3 & $\mu \mathrm{g} \cdot \mathrm{g}^{-1}$ & 4.6 & $4.4 \pm 1.2$ \\
TILL 1 & $\mu \mathrm{g} \cdot \mathrm{g}^{-1}$ & 2.2 & $1.9 \pm 0.6$ \\
TILL 3 & $\mu \mathrm{g} \cdot \mathrm{g}^{-1}$ & 2.1 & $1.8 \pm 0.5$ \\
STSD-1 & $\mu \mathrm{g} \cdot \mathrm{g}^{-1}$ & 8.0 & $7.8 \pm 1.3$ \\
\hline
\end{tabular}

Table4. Excess Radiological Risk for ground water Uranium at various distance regions (2003-07).

\begin{tabular}{ccc}
\hline Distance & $\mathbf{U}\left(\mathbf{m g}^{-3} \mathbf{m}^{-3}\right.$ Geo mean & Excess Radiological Risk \\
\hline$<1.5 \mathrm{~km}$ & 2.29 & $6.06 \times 10^{-6}$ \\
$1.5 \mathrm{~km}-5 \mathrm{~km}$ & 1.62 & $4.31 \times 10^{-6}$ \\
$>5 \mathrm{~km}$ & 1.17 & $3.11 \times 10^{-6}$ \\
\hline
\end{tabular}

Table 5. Comparison of uranium concentration in drinking water in different countries.

\begin{tabular}{ccc}
\hline Country & Range of $\mathrm{U}\left(\mu \mathrm{g} \cdot \mathrm{l}^{-1}\right)$ & References \\
\hline Turkey & $0.24-17.65$ & Kumru at al. [10] \\
South Greenland & $0.5-1.0$ & Brown et al [18] \\
USA & $0.01-652$ & Cothern et al [11] \\
Kuwait & $0.02-2.48$ & Bou-Rabee et al [12] \\
Jordan & $0.04-1400$ & Smith et al [19] \\
Central Austrlia & $>20$ & Hostetler et al [20] \\
Cochin, India & $0.34-2.54$ & Prabhu R.S. et al [21] \\
Jaduguda, India & $0.50-28$ & Present Study \\
\hline
\end{tabular}

reference man (4.05 liter per day) were considered. The average life expectancy in India is 60 years was considered as total exposure period. Finally the radiological risk coefficient was estimated as $1.06 \times 10^{-4}$ in the Indian scenario.

The illustrative calculation is:

Risk Factor (per Bq. $\left.1^{-1}\right)=$ Risk coefficient $(4.40 \mathrm{E}-11)$ $\times$ water ingestion rate $\left(4.051 \cdot\right.$ day $\left.^{-1}\right)$ total exposure duration $(21,900$ day $) \times$ conversion factor $\left(27 \mathrm{pCi} \cdot \mathrm{Bq}^{-1}\right)=$ $1.06 \times 10^{-4} \mathrm{~Bq} \cdot 1^{-1}$.

Excess life time cancer Risk $=$ uranium level $\left(\right.$ Bq. $\left.1^{-1}\right) x$ Risk factor $\left(1.06 \times 10^{-4} \mathrm{~Bq} \cdot \mathrm{l}^{-1}\right)$.

The radiological risk estimated is presented in Table 4. The risk was found to be in the order of $10^{-6}$ and much below the acceptable radiological risk of $10^{-3}[7]$. Hence, the radiological risk due to natural uranium in ground water might be acceptable and the uranium mining industry has insignificant impact in the ground water ura- nium concentration of the study area.

\section{Conclusions}

The distribution of $U(n a t)$ in ground water reflects the natural background of the area. The variation in concentration at different distances may be attributed to the geological features of the area and the physicochemical environment around the source. A slight reduced uranium concentration in the $<1.5 \mathrm{~km}$ or closest to uranium industry may be attributed to the soil/rock type around the ground water sources. The highest concentration of uranium was found to be $28 \mu \mathrm{g} \cdot l^{-1}$ is away ( 1.5 to $5 \mathrm{~km}$ distance zone) from mining industry. The intake and ingestion dose is appreciably low $\left(2 \mu \mathrm{Sv} \cdot \mathrm{Y}^{-1}\right)$ which is far below the WHO recommended level of $100 \mu \mathrm{Sv} \cdot \mathrm{Y}^{-1}$. The risk due to radiological is acceptable and very low. It can be concluded that the ground water around the uranium 
industry at Jaduguda is not affected by the uranium mining activity. The drinking water studied in three different distance zones of uranium mining facility found to be safe.

\section{REFERENCES}

[1] “Ask the Expert," Health Physics Society, April 2002. http://www.hps.org/publicinformation/ate/q1906.html

[2] P. W. Durbin, "Metabolic Model for Uranium," In: R. H. Moore, Ed, Biokinetics and Analysis in Man 1984, United States Uranium Registry, National Technical Information Service, Springfield, 1984.

[3] J. B. Hursh and N. L. Spoor, "Data on Man," In: H. C. Hodge, J. N. Stannard and J. B. Hursh, Eds., Uranium, Plutonium, Transplutonium Elements, Springer-Verlag, Berlin, 1973, pp. 197-239.

[4] A. J. Lussenhop, J. C. Gallimore, W. H. Sweet, E. G. Struxness and J. Robinson, "The Toxicity in Man of Hexavalent Uranium Following Intravenous Administration," American Journal of Roentgenology, Vol. 79, No. 1, 1958, pp. 83-100.

[5] S. C. Morris and A. F. Meinhold, "Probabilistic Risk Assessment of Nephrotoxic Effect of Uranium in Drinking Water," Health Physics, Vol. 69, No. 6, 1995, pp. 897-908. doi:10.1097/00004032-199512000-00003

[6] U.S. EPA, Draft Guidelines for Carcinogen Risk Assessment (Review Draft, July 1999), U. S. Environmental Protection Agency, Risk Assessment Forum, Washington, D.C., 1999.

[7] D. C. Shin, Y. S. Kim, J. Y. Moon, H. S. Park, J. Y. Kim and S. K. Park, "International Trends in Risk Management of Groundwater Radionuclides," Journal of Environmental Toxicology, Vol. 17, No. 4, 2002, pp. 273-284.

[8] K. P. Eappan and P. M. Markose, "Amine Extraction for Uranium Estimation," Bulletin of Radiation Protection, Vol. 9, 1986, pp. 83-86

[9] I. M. Kolthoff and P. J. Eiving, "Treatise on Analytical Chemistry, Part II. Vol. 9," Wiley, New York, 1962, pp. 102-111.

[10] M. N. Kumru, "Distribution of Radionuclides in Sediments and Soils along the Buyuk Mendres River," Proceeding of Pakistan Academy of Sciences, Vol.32, 1995, pp. 51-56

[11] C. R. Cotheren and W. L. Lappenbusch, "Occurance of
Uranium in Drinking Water in the US," Health Physics, Vol. 45, No. 1, 1983, pp. 89-99. doi:10.1097/00004032-198307000-00009

[12] F. Bou-Rabee, "Estimating the Concentration of Uranium in Some Environmental Samples in Kuwait after the 1991 Gulf War," Applied Radiation and Isotopes, Vol. 46. No. 4, 1995, pp. 217-220. doi:10.1016/0969-8043(94)00122-G

[13] B. M. Raghunath and S. D. Soman, "Water Intake Data for Indian Reference Man," Indian Journal of Environmental Health, Vol. 2, 1969, pp. 1-7.

[14] H. S. Dang, D. D. Jaiswal, M. Parameswaran and S. Krishnamony, "Physical, Anatomical, Physiological and Metabolic Data for Reference Indian Man-A Proposal," Bhabha Atomic Research Centre, Mumbai, 1994.

[15] "Dose Coefficients for Intakes of Radionuclides by Workers," International Commission on Radiological Protection Series, Annals of the ICRP, Elsevier Health Sciences, Amsterdam, 1995.

[16] WHO, Guidelines for Drinking-water Quality, Volume 1, Recommendations, 2004.

[17] SEPA, National Primary Drinking Water Regulation Radionuclide, Final Rule, 2000.

[18] A. Brown, A. Steenfelt and H. Kunzennorf, "Uranium Districts Defined by Reconnaissance Geo Chemistry in South Greenland," Journal of Geochemical Exploration, Vol. 19, No. 1-3, 1983, pp. 127-145. doi:10.1016/0375-6742(83)90013-4

[19] B. Smith, A. E. Powel, A. Milodowski, et al., "Identification, Investigation and Remediation of Ground Water Containing Elevated Level of Uranium-Series Radionuclides: A Case Study from the Easteron Mediterranean," Proceddings of the 3rd International Conference on the Geology of the Easteren Mediterranean, Nicosia, Cyprus, 2000.

[20] S. Hostetler, J. Wischisen and G. Jacbson, "Ground Water Quality in the Papunya-Kingtore Region Northen Territory," Austrilian Geological Survey Organization, Canberra, 1998.

[21] R. S. Prabhu, R. Sathyapriya, S. K. Sahoo and S. Mahapatra, "Ingestion Dose Due to Natural Uranium to the Public through Drinking Water Pathways in Two Districts of Keral," Proceedings of 16th National Symposium on Environment, Hisar, 2008, pp. 551-555. 